Vol. 44, N. 3 : pp. 227 - 231, September, 2001

ISSN 1516-8913 Printed in Brazil

\title{
A Chemically Defined Medium for Production of Actinomycin D by Streptomyces parvulus
}

\author{
Maria de Fátima Vieira de Queiroz Sousa ${ }^{1 *}$, Carlos Edison Lopes ${ }^{1}$ and Nei Pereira Júnior ${ }^{2}$ \\ ${ }^{I}$ Departmento de Antibióticos, Centro de Ciências Biológicas da Universidade Federal de Pernambuco, Recife, \\ 50670-901, Pernambuco, ${ }^{2}$ Departamento de Engenharia Bioquímica, Escola de Química da Universidade Federal \\ do Rio de Janeiro, Rio de Janeiro 21949-900, Brasil
}

\begin{abstract}
A chemically defined medium consisting of $\mathrm{D}(+)$ fructose, $\mathrm{L}(-)$ threonine, $\mathrm{K}_{2} \mathrm{HPO}_{4}, \mathrm{MgSO}_{4} .7 \mathrm{H}_{2} \mathrm{O}, \mathrm{ZnSO}_{4} .7 \mathrm{H}_{2} \mathrm{O}$, $\mathrm{CaCl}_{2} \cdot 2 \mathrm{H}_{2} \mathrm{O}, \mathrm{FeSO}_{4} \cdot 7 \mathrm{H}_{2} \mathrm{O}$ and deionized water, was developed to maximize the synthesis of actinomycin $\mathrm{D}$ by the Streptomyces parvulus DAUFPE 3124 strain. This medium resulted in the maximum antibiotic concentration of $133 \mathrm{mg} / \mathrm{L}$ while using the original medium the production of actinomycin $D$ was poor not surpassing $43 \mathrm{mg} / \mathrm{L}$.
\end{abstract}

Key words : Actinomycin D, production, Streptomyces. parvulus, synthetic medium

\section{INTRODUCTION}

The actinomycins are a family of chromopeptide antibiotics that present antitumoral properties, being employed in the treatment of several human neoplasies (Waksman \& Furness, 1960). Structurally, they have a chromophorous group, identical in all actinomycins, and two pentapeptide chains with a variable composition of amino acids (Brockmann, 1960). They are synthesized by Streptomyces as mixtures of different actinomycins, however, the $S$. parvulus species produces actinomycin $\mathrm{D}$ almost exclusively (>95\%) (Meienhofer \& Atherton, 1973). Over the last ten years, research into actinomycin D has been directed mainly towards clinical applications and no work related to production was found. In a previous study the authors optimized a complex medium for the production of actinomycin D by $S$. parvulus DAUFPE 3124 strain, increasing the final antibiotic concentration from $245 \mathrm{mg} / \mathrm{L}$ to $530 \mathrm{mg} / \mathrm{L}$ (Sousa, et al., 1997). Few papers have been found that focus on the nutritional requirements of Streptomyces species for achieving a high actinomycin yield (Katz et al.,1958; Williams \& Katz, 1977). Katz et al. (1958) showed that the maximum antibiotic synthesis ocurred in a chemically defined medium containing L(-) galactose $(10 \mathrm{~g} / \mathrm{L}), \mathrm{L}(-)$ glutamic acid $(2 \mathrm{~g} / \mathrm{L})$, phosphate $(1 \mathrm{~g} / \mathrm{L})$ and mineral salts. Although this composition proved to be satisfactory for production of actinomycin mixtures by $S$. antibioticus, the synthesis of actinomycin D by $S$. parvulus was rather poor and extremely variable. Williams \& Katz (1977) proposed a chemically defined medium for the synthesis of high yields (500 to $600 \mathrm{mg} / \mathrm{L}$ ) of actinomycin D by $S$. parvulus ATCC 12434 . Dalili \& Chau, (1988) working with the same medium and the same strain immobilized in calcium alginate, using an air lift column operating under discontinuous, fed batch and continuous conditions, obtained 50, 73 and $80 \mathrm{mg} / \mathrm{L}$, respectively. However, since nutritional requirements for growth and product formation vary from strain to strain, the medium suggested by Williams \& Katz (1977) resulted in a low antibiotic production by the $S$. parvulus DAUFPE

\footnotetext{
${ }^{*}$ Author for correspondence
} 
3124 strain. This work presents a set of experiments that culminated in the development of a chemically defined medium in which higher concentration of actinomycin D was achieved using the $S$. parvulus DAUFPE 3124 strain.

\section{MATERIALS AND METHODS}

Microorganism: Streptomyces parvulus DAUFPE 3124 strain was used in all assays. This strain was maintained on slants of $4 \mathrm{~g} / \mathrm{L}$ glucose, $4 \mathrm{~g} / \mathrm{L}$ yeast extract and $10 \mathrm{~g} / \mathrm{L}$ malt extract agar medium. Incubation was carried out for 3 to 5 days at $30^{\circ} \mathrm{C}$ until gray spores developed and the slants were stored at $4^{\circ} \mathrm{C}$.

Preparation of Spore Suspension: The spores were scraped from the surface of heavily sporulated slants with $3 \mathrm{ml}$ of $9 \mathrm{~g} / \mathrm{L} \mathrm{NaCl}$ solution containing $1 \mathrm{ml} / \mathrm{L}$ of Tween 80, following the Hopwood et al., (1985) technique. The spore concentration was quantified in the suspension and stored in the freezer at $-4^{\circ} \mathrm{C}$.

Growth and Production Media: The medium used during the biomass growth had the following composition: $5 \mathrm{~g} / \mathrm{L}$ tryptone and $3 \mathrm{~g} / \mathrm{L}$ yeast extract. In the antibiotic production several media were used with $\mathrm{pH}$ adjusted to 7.0 and in all of them, the following basal mineral salts medium $\mathrm{K}_{2} \mathrm{HPO}_{4} \quad 1.0 \quad \mathrm{~g} / \mathrm{L} ; \quad \mathrm{MgSO}_{4} .7 \mathrm{H}_{2} \mathrm{O}$ $25 \mathrm{mg} / \mathrm{L} ; \mathrm{ZnSO}_{4} .7 \mathrm{H}_{2} \mathrm{O} 25 \mathrm{mg} / \mathrm{L} ; \mathrm{CaCl}_{2} .2 \mathrm{H}_{2} \mathrm{O}$ $25 \mathrm{mg} / \mathrm{L} ; \mathrm{FeSO}_{4} .7 \mathrm{H}_{2} \mathrm{O} 25 \mathrm{mg} / \mathrm{L}$ was used. A number of amino acids and carbohydrates were tested as carbon and nitrogen sources so that the $\mathrm{C} / \mathrm{N}$ ratio was held around 41.7 , as recommended by Williams \& Katz (1977), and several C/N ratios were employed when the best carbon and nitrogen sources were selected. The amino acids, carbohydrates and salts were sterilized separately and added just prior to inoculation.

Experimental Procedure: The growth was performed in two steps. In the first one, the inoculum was prepared in a $250 \mathrm{ml}$ flask containing $25 \mathrm{ml}$ of growth medium inoculated with $50 \mu \mathrm{l}$ of spore suspension $\left(8.0 \times 10^{7}\right.$ $\mathrm{cfu} / \mathrm{ml}$ ). The flasks were placed on a rotary shaker at $250 \mathrm{rpm}$ at $30^{\circ} \mathrm{C}$ for $48 \mathrm{~h}$. In the second step, 20 $\mathrm{ml}$ of the mycelial suspension was used to inoculate a $2000 \mathrm{ml}$ flask containing $200 \mathrm{ml}$ of growth medium which was subjected to the same conditions as described above for $24 \mathrm{~h}$. The antibiotic production was conducted in $500 \mathrm{ml}$ shaken flasks, containing $50 \mathrm{ml}$ of the fermentation medium. These flasks were inoculated with $3 \mathrm{ml}$ of mycelial suspensions and subjected to the same conditions as cited above. Samples were taken at 24 hour intervals and analysed in terms of actinomycin D concentration by spectrophotometric method (Katz \& Weissbach, 1963). The data reported in all experiments represent the yield of actinomycin D for 144 hours of cultivation except for the last one.

\section{RESULTS AND DISCUSSION}

As observed by Williams \& Katz (1977), the association of L(-)glutamic acid with another amino acid potentialized the synthesis of actinomycin D by $S$. parvulus ATCC 12434 . This fact was tested using the $S$. parvulus DAUFPE 3124 and the results are shown in the Table 1. This table shows that a maximum concentration of actinomycin D was obtained when the L(-) glutamic acid was combined with L(-)histidine, $\mathrm{L}(-)$ ornithine or L(-)threonine $(70.8 \mathrm{mg} / \mathrm{L})$.

Table 1 - Effect of L(-) amino acids provided in combination with L(-) glutamic acid for actinomycin production by $S$. parvulus DAUFPE 3124 grown in a 40 $\mathrm{g} / \mathrm{L} \mathrm{D}(+)$ fructose, $2.2 \mathrm{~g} / \mathrm{L} \mathrm{L(-)} \mathrm{glutamic} \mathrm{acid} \mathrm{basal}$ mineral salts medium for $144 \mathrm{~h}$ at $30^{\circ} \mathrm{C}(\mathrm{C} / \mathrm{N}$ ratios between 41.2 and 42.8$)$.

\begin{tabular}{cc}
\hline $\begin{array}{l}\mathrm{L}(-) \text { glutamic acid }+ \\
\mathrm{L}(-) \text { amino acids }(\mathrm{g} / \mathrm{L})\end{array}$ & $\begin{array}{c}\text { Actinomycin D } \\
(\mathrm{mg} / \mathrm{L})\end{array}$ \\
\hline Histidine $(0.775)$ & 70.8 \\
Ornithine $(0.99)$ & 70.8 \\
Threonine $(1.787)$ & 70.8 \\
Alanine $(1.336)$ & 65.0 \\
Leucine $(1.967)$ & 62.7 \\
Glutamine $(1.096)$ & 38.6 \\
Glicine $(1.126)$ & 47.3 \\
Valine $(1.757)$ & 53.7 \\
Proline $(1.727)$ & 68.5 \\
Serine $(1.576)$ & 22.1 \\
Asparagine $(0.99)$ & 53.7 \\
Tryptophan $(1.53)$ & 42.1 \\
Methionine $(2.387)$ & 18.4 \\
\hline
\end{tabular}

Assays were carried out with several $\mathrm{L}(-)$ amino acids to determine the one more 
appropriated for antibiotic synthesis (Table 2). The best result $(87.7 \mathrm{mg} / \mathrm{L})$ was achieved when $\mathrm{L}(-)$ threonine was the sole nitrogen source. Surprisingly, this result was higher than the one obtained $(70.8 \mathrm{mg} / \mathrm{L})$ by the combination of $\mathrm{L}(-)$ glutamic acid and L(-) threonine. In the literature there is no explanation for this effect and, furthermore, it results in a cheaper chemically defined medium composition.

Table 2 - Effect of L(-) amino acids in actinomycin D production by $S$. parvulus DAUFPE 3124 grown in a 20 $\mathrm{g} / \mathrm{L} \mathrm{D}(+)$ fructose basal mineral salts medium for $144 \mathrm{~h}$ at $30^{\circ} \mathrm{C}(\mathrm{C} / \mathrm{N}$ ratios between 38.9 and 43.3$)$

\begin{tabular}{cc}
\hline $\mathrm{L}(-)$ amino acids $(\mathrm{g} / \mathrm{L})$ & $\begin{array}{c}\text { Actinomycin D } \\
(\mathrm{mg} / \mathrm{L})\end{array}$ \\
\hline Threonine $(1.785)$ & 87.7 \\
Ornithine $(0.99)$ & 34.6 \\
Histidine $(0.775)$ & 77.1 \\
Alanine $(0.445)$ & 49.8 \\
Leucine $(1.96)$ & 16.6 \\
Glutamine $(1.1)$ & 70.2 \\
Glicine $(1.125)$ & 82.0 \\
Valine $(1.75)$ & 74.0 \\
Proline $(1.725)$ & 77.1 \\
Aspartic acid (1.1) & 35.7 \\
Asparagine $(1.0)$ & 84.5 \\
Glutamic acid (2.2) & 54.7 \\
Methionine $(2.2)$ & 7.7 \\
\hline
\end{tabular}

L(-) threonine is one of the amino acids constituents of the actinomycin molecules. Katz et al. (1965) employed labeled L(-) threonine $-{ }^{14} \mathrm{C}$ in experiments of short incubation and verified that $S$. antibioticus strains metabolizes this amino acid in both protein and actinomycin synthesis. Due to this evidence, these authors came to the conclusion that there is an intracellular pool of threonine commom to the two synthesizer systems although these systems were differents.

A number of carbohydrates were investigated as carbon sources for actinomycin-D production employing the basal mineral salts medium with 1.8 $\mathrm{g} / \mathrm{L}$ of threonine and the results can be seen in Table 3. This table shows that $\mathrm{D}(+)$ fructose was superior to the others carbohydrates tested in the same concentration. This result agrees with the findings of Williams \& Katz (1977), who affirmed that $\mathrm{D}$ fructose was the most effective carbon source for antibiotic synthesis by $S$. parvulus. No actinomycin-D production was detected when glucose and galactose were employed as sole carbon sources. Gallo \& Katz (1972) demonstrated that glucose supports a rapid growth rate of $S$. antibioticus, but it exerts severe catabolite repression in antibiotic production, particulary in the synthesis of phenoxazinone synthase, an essential enzyme for the formation of the actinomycin chromophorous group. Williams \& Katz (1977) working with S. parvulus ATCC 12434, also showed the repression caused by glucose additions to a chemically defined medium containing fructose $(40 \mathrm{~g} / \mathrm{L})$ as the main substrate. Marshall et al. (1968) verified the inhibitory effect of galactose on phenoxazinone synthetase specific activity in cells of $S$. antibioticus harvested after six hours of incubation.

Table 3 - Influence of several carbon sources on actinomycin production by $S$. parvulus DAUFPE 3124 grown in a $1.8 \mathrm{~g} / \mathrm{L} \mathrm{L(-)} \mathrm{threonine} \mathrm{basal} \mathrm{mineral} \mathrm{salts}$ medium for $144 \mathrm{~h}$ at $30^{\circ} \mathrm{C}(\mathrm{C} / \mathrm{N}=41.5)$

\begin{tabular}{cc}
\hline Carbon sources $(20 \mathrm{~g} / \mathrm{L})$ & $\begin{array}{c}\text { Actinomycin } \mathrm{D} \\
(\mathrm{mg} / \mathrm{L})\end{array}$ \\
\hline $\mathrm{D}(-)$ arabinose & 5.3 \\
$\mathrm{D}(+)$ fructose & 55.8 \\
$\mathrm{D}(-)$ galactose & $\mathrm{ND}^{*}$ \\
$\mathrm{D}(+)$ glucose & $\mathrm{ND}^{*}$ \\
Myo-inositol & 43.2 \\
$\mathrm{D}(-)$ manytol & 36.2 \\
$\mathrm{D}(+)$ manose & 18.2 \\
Sucrose & 21.6 \\
$\mathrm{D}(+)$ xylose & 44.8 \\
\hline${ }^{\mathrm{N} D}$ - not detected &
\end{tabular}

To evaluate the quantitative influence of $\mathrm{C} / \mathrm{N}$ ratios upon antibiotic synthesis by $S$. parvulus DAUFPE 3124, the concentration of $\mathrm{D}(+)$ fructose $(20 \mathrm{~g} / \mathrm{L})$ was held constant while the amount of $\mathrm{L}(-)$ threonine was varied to provide different $\mathrm{C} / \mathrm{N}$ ratios in the medium. The results of these experiments are shown in Table 4.

Higher production of actinomycin-D $(67.9 \mathrm{mg} / \mathrm{L})$ was achieved at $\mathrm{C} / \mathrm{N}$ ratio of 22.5 which corresponded to $20 \mathrm{~g} / \mathrm{L} \mathrm{D}(+)$ fructose and $3.57 \mathrm{~g} / \mathrm{L} \mathrm{L}(-)$ threonine.

Comparative study of the medium reported by Williams \& Katz (1977) and the one developed in this work was done employing $S$. parvulus DAUFPE 3124 strain. The concentration curves of actinomycin $\mathrm{D}$ production are shown in Figure 1 where can see that the antibiotic concentration reached the maximum value of 133 $\mathrm{mg} / \mathrm{L}$ in the proposed medium and in the medium suggested by cited authors the maximum value was $43 \mathrm{mg} / \mathrm{L}$. 
Table 4 - Effect of several C/N ratios on actinomycin D production by $S$. parvulus DAUFPE 3124 grown in a basal mineral salts medium for $144 \mathrm{~h}$ at $30^{\circ} \mathrm{C}$.

\begin{tabular}{cccc}
\hline $\begin{array}{c}\mathrm{D}(+) \\
\begin{array}{c}\text { Fructose } \\
(\mathrm{g} / \mathrm{L})\end{array}\end{array}$ & $\begin{array}{c}\mathrm{L}(-) \\
\text { Threonine } \\
(\mathrm{g} / \mathrm{L})\end{array}$ & $\mathrm{C} / \mathrm{N}$ & $\begin{array}{c}\text { Actinomycin D } \\
(\mathrm{mg} / \mathrm{L})\end{array}$ \\
\hline 20 & 3.57 & 22.5 & 67.9 \\
20 & 2.38 & 32.0 & 57.5 \\
20 & 1.78 & 41.6 & 58.9 \\
20 & 1.19 & 60.6 & 53.8 \\
\hline
\end{tabular}

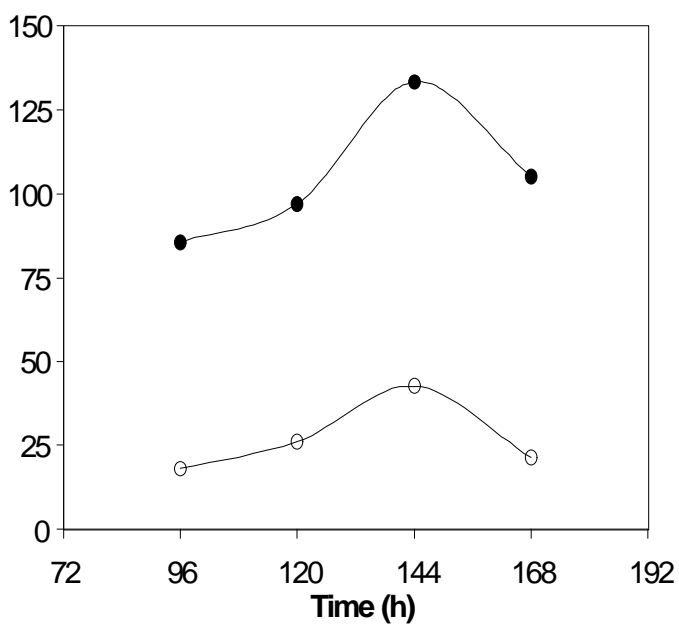

Figure 1 - Actinomycin D concentrations obtained in shaken flasks by $S$. parvulus DAUFPE 3124, using chemically defined media $(O)$ reported by Williams \& Katz (1977) and (•) suggested by present work.

The results clearly show the dependence of the antibiotic synthesis on medium constituents. The medium developed in this study to obtain high yield of actinomycin D by $S$. parvulus DAUFPE 3124 has the following composition: $20 \mathrm{~g} / \mathrm{L} \mathrm{D}(+)$ fructose; $3.57 \mathrm{~g} / \mathrm{L} \mathrm{L(-)} \mathrm{threonine;} 1.0 \mathrm{~g} / \mathrm{L} \mathrm{K}_{2} \mathrm{HPO}_{4}$; $25 \mathrm{mg} / \mathrm{L} \mathrm{MgSO}{ }_{4} .7 \mathrm{H}_{2} \mathrm{O}, 25 \mathrm{mg} / \mathrm{L} \mathrm{ZnSO}_{4} .7 \mathrm{H}_{2} \mathrm{O}, 25$ $\mathrm{mg} / \mathrm{L} \quad \mathrm{CaCl}_{2} \cdot 2 \mathrm{H}_{2} \mathrm{O}$ and $25 \mathrm{mg} / \mathrm{L} \mathrm{FeSO}{ }_{4} \cdot 7 \mathrm{H}_{2} \mathrm{O}$. This composition allowed an improvement of over $200 \%$ in the concentration of actinomycin D.

\section{ACKNOWLEDGMENTS}

This work was supported in part by Fundação de Amparo à Ciência e Tecnologia do Estado de Pernambuco.

\section{RESUMO}

Um meio quimicamente definido composto de D (+) frutose, L (-) treonina, $\mathrm{K}_{2} \mathrm{HPO}_{4}$, $\mathrm{MgSO}_{4} .7 \mathrm{H}_{2} \mathrm{O}, \quad \mathrm{ZnSO}_{4} .7 \mathrm{H}_{2} \mathrm{O}, \quad \mathrm{CaCl}_{2} .2 \mathrm{H}_{2} \mathrm{O}$, $\mathrm{FeSO}_{4} \cdot 7 \mathrm{H}_{2} \mathrm{O}$ e água deionizada, foi desenvolvido para maximizar a síntese de actinomicina D pelo Streptomyces parvulus DAUFPE 3124. O meio proposto resultou numa concentração antibiótica máxima de $133 \mathrm{mg} / \mathrm{L}$ enquanto que no meio inicial a produção antibiótica foi baixa, não ultrapassando $43 \mathrm{mg} / \mathrm{L}$.

\section{REFERENCES}

Brockmann, H. (1960), Structural differences of the actinomycins and their derivatives. Ann. N. Y. Acad. Sci. 89, 323-335

Dalili, M. and Chau, P. C. (1988), Production of actinomycin D with immobilized Streptomyces parvulus under nitrogen and carbon starvation conditions. Biotechnol. Lett. 10, 331-336

Gallo, M. and Katz, E. (1972), Regulation of secundary metabolite biosynthesis catabolic repression of phenoxazinone synthase and actinomycin formation by glucose. J. Bacteriol. 109, 659-667

Hopwood, D. A.; Bibb, M. J.; Chater, K. F.; Kieser, T.; Bruton, C. J.; Kieser, H. M.; Lydiate, D. J.; Smith, C. P.; Ward, J. M. and Schrempf, H. (1985), Genetic manipulation of Streptomyces: a laboratory manual. The John Innes Foundation, Norwich, 2-9

Katz, E.; Pienta, P. and Sivak, A. (1958), The role of nutrition in the synthesis of actinomycin. Appl. Microbiol. 6, 236-241

Katz, E. and Weissbach, H. (1963), Incorporation of ${ }^{14} \mathrm{C}$-labeled amino acids into actinomycin and protein by $S$. antibioticus. J. Biol. Chem. 238, 666-675

Katz, E.; Wise, M. and Weissbach, H. (1965), Actinomycin Biosynthessis: differential effect of chloramphenicol on protein and peptide antibiotic synthesis. J. Biol. Chem. 240, 3071-3078

Marshall, R.; Redfield, B.; Katz, E. and Weissbach, H. (1968), Changes in phenoxazinone synthetase activity during the growth cycle of S. antibioticus. Arch. Biochem. Biophys. 123, 317-323

Meienhofer, J. and Atherton, E. (1973), Structureactivity relationship in the actinomycins. Adv. Appl. Microbiol.16, 203-300

Sousa, M. F. V. Q.; Lopes, C. E. and Pereira Jr., N. (1977), Medium optimization for the production of actinomycin-D by Streptomyces parvulus. Arq. Biol. Tecnol. 40, 405-411

Waksman, S. A. and Furness, F. N. (1960), The actinomycins and their importance in the treatment of tumors in animals and man. Ann. N. Y. Acad. Sci., 89, 283-486 
Williams, W. K. and Katz, E. (1977), Development of a chemically defined medium for the synthesis of actinomycin D by Streptomyces parvulus. Antimicrob. Agents Chemother, 11, 281-290
Received: July 05,2000 ; Revised: September 21, 2000; Accepted: November 30, 2000. 